\title{
Endoparasites of Eleven Species of Ranid Frogs (Anura: Ranidae) from Papua New Guinea ${ }^{1}$
}

\author{
Stephen R. Goldberg, ${ }^{2,3,5}$ Charles R. Bursey, ${ }^{4}$ and Fred Kraus ${ }^{5}$
}

\begin{abstract}
Two hundred eighty-eight ranid frogs from Papua New Guinea collected from 2002 to 2005 were examined for endoparasites: Platymantis adiastolus, P. boulengeri, P. browni, P. gilliardi, P. papuensis, P. schmidti, Rana daemeli, $R$. garritor, $R$. jimiensis, $R$. milneana, and $R$. papua. Found were one species of Cestoda (as cysticerci), three species of Digenea (Opisthioglyphe cophixali, Diplodiscus amphichrus, and Mesocoelium monas), 18 species of Nematoda (adults of Abbreviata oligopapillata, Aplectana krausi, Aplectana macintoshii, Aplectana zweifeli, Cosmocerca novaeguineae, C. tyleri, Desmognathinema papuensis, Falcaustra papuensis, Icosiella papuensis, Meteterakis crombiei, Ochoterenella papuensis, Paracapillaria spratti, Pseudorictularia dipsarilis, Rhabdias australiensis, Seuratascaris numidica, larvae of Abbreviata sp., and Ascaridae gen. sp.), two species of Acanthocephala (Acanthocephalus bufonis and cystacanths of a second species), and one species of Pentastomida (nymphs of Kiricephalus sp.). Sixty-seven new host records, one new country record, and several new island records are reported. Nematodes composed 18/24 (75\%) of the species present. Thirteen of the 24 endoparasite species found currently appear to be endemic to Papua New Guinea.
\end{abstract}

The family Ranidae has an almost worldwide distribution and is well represented in Papua New Guinea, where eight genera with more than 50 species have been reported (Menzies 2006). To our knowledge endoparasite records are available for seven Papua New Guinean ranid species: Platymantis boulengeri, P. nexipus, P. papuensis, Rana arfaki, $R$. "grisea," R. grunniens, and R. supragrisea (Schmidt 1975, Moravec and Sey 1989, 1990, Bursey and Goldberg 2007, Bursey et al.

\footnotetext{
${ }^{1}$ This research was supported by National Science Foundation grant DEB 0103794. This is contribution 2008-034 from the Pacific Biological Survey at the Bishop Museum. Manuscript accepted 14 October 2008.

2 Corresponding author.

${ }^{3}$ Department of Biology, Whittier College, Whittier, California 90608 (e-mail: sgoldberg@whittier.edu).

${ }^{4}$ Department of Biology, Pennsylvania State University, Shenango Campus, Sharon, Pennsylvania 16146 (e-mail: cxb@psu.edu).

${ }^{5}$ Bernice P. Bishop Museum, Department of Natural Sciences, 1525 Bernice Street, Honolulu, Hawai'i 96817 (e-mail: fkraus@hawaii.edu).
}

Pacific Science (2009), vol. 63, no. 3:327-337

(C) 2009 by University of Hawai'i Press

All rights reserved
2008, 2009). In this paper we present endoparasitological records for six species of Platymantis ( $P$. adiastolus Brown, Richards, Sukumaran \& Foupoulos, 2006; P. boulengeri [Boettger, 1892]; P. browni Allison \& Kraus, 2001; P. gilliardi Zweifel, 1960; P. papuensis Meyer, 1875; P. schmidti Brown \& Tyler, $1968)$ and five species of Rana ( $R$. daemeli [Steindachner, 1868]; Rana garritor Menzies, 1987; Rana jimiensis Tyler, 1963; Rana milneana Loveridge, 1948; Rana papua Lesson, 1827), and we establish the initial helminth lists for $P$. adiastolus, $P$. browni, $P$. gilliardi, $P$. schmidti, $R$. daemeli, $R$. garritor, $R$. jimiensis, $R$. milneana, and $R$. papua.

\section{MATERIALS AND METHODS}

Two hundred eighty-eight frogs representing 11 species of Ranidae collected by hand in Papua New Guinea from 2002 to 2005 were examined for endoparasites: Platymantis adiastolus $(n=22), P$. boulengeri $(n=41), P$. browni $(n=24), P$. gilliardi $(n=12), P$. papuensis $(n=53)$, P. schmidti $(n=33)$, Rana daemeli $(n=24), \quad R$. garritor $(n=26), \quad R$. jimiensis $(n=11), R$. milneana $(n=25)$, and $R$. papua $(n=17)$. These ranid species all came from 
the main island of New Guinea, with the exception of Platymantis papuensis, which all came from the offshore island of New Britain, and Rana daemeli. Immediately after capture frogs were euthanized, fixed in neutral buffered $10 \%$ formalin, stored in $70 \%$ ethanol, and accessioned in the herpetology collection of the Bernice P. Bishop Museum (врвм), Honolulu, Hawai'i (Appendix 1). Subsequently, the body cavity was opened by a longitudinal abdominal incision and the gastrointestinal tract was removed by cutting across the esophagus and the rectum and then shipped in a vial of alcohol to Whittier College, Whittier, California, where a detailed dissection of each part of the tract was carried out using a dissecting microscope. Endoparasites from individual hosts were removed to vials of $70 \%$ ethanol and later placed under a coverslip in a drop of lactophenol and allowed to clear. Nematodes and acanthocephalans were identified from these preparations. Digeneans, cestodes, and pentastomes were washed in water, regressively stained in hematoxylin, and mounted in balsam for identification under a compound microscope. Parasite terminology is in accordance with Bush et al. (1997): prevalence (number infected hosts/number hosts examined $\times 100$ ), mean intensity (mean number of helminths per infected host \pm 1 standard deviation). Voucher specimens were deposited in the U.S. National Parasite Collection (USNPC), Beltsville, Maryland, or the Bernice P. Bishop Museum (врвм) (Appendix 2).

\section{RESULTS}

A total of 3,644 endoparasites was recovered from $229(80 \%)$ of 288 frogs. Of these, 2,790 (77\% of total) were mature individuals representing three species of Digenea (Diplodiscus amphichrus Tubangui, 1933; Mesocoelium monas [Rudolphi, 1819] Freitas, 1957; Opisthioglyphe cophixali Moravec \& Sey, 1989); 15 species of Nematoda (Abbreviata oligopapillata [Kreis, 1940] Morgan, 1945; Aplectana krausi Bursey \& Goldberg, 2007; Aplectana macintoshii [Stewart, 1914] Travassos, 1931; Aplectana zweifeli Moravec \& Sey, 1986; Cos- mocerca novaeguineae Moravec \& Sey, 1990; Cosmocerca tyleri Bursey, Goldberg \& Kraus, 2006; Desmognathinema papuensis Moravec \& Sey, 1990; Falcaustra papuensis Bursey, Goldberg \& Kraus, 2007; Icosiella papuensis Johnston, 1967; Meteterakis crombiei Bursey, Goldberg \& Kraus, 2005; Ochoterenella papuensis Johnston, 1967; Paracapillaria spratti [Moravec \& Sey, 1986]; Pseudorictularia dipsarilis [Irwin-Smith, 1922] Dollfus \& Desportes, 1944; Rhabdias australiensis Moravec \& Sey, 1990; Seuratascaris numidica [Seurat, 1917]; and one species of Acanthocephala (Acanthocephalus bufonis [Shipley, 1903]). Also present were 854 (23\% of total) juvenile endoparasites presumably incapable of completing their life cycles in frogs: one species of Cestoda (as cysticerci), two species of Nematoda (Abbreviata sp. and Ascaridae gen. sp.), one species of Acanthocephala (as cystacanths), and one species of Pentastomida (nymphs of Kiricephalus sp.). Number of parasites, prevalence, mean intensity and range of infection, site of infection, and new host records are given in Table 1.

Although 24 species of endoparasites occurred in the sample, no host species harbored more than 13 species of endoparasites (mean number of endoparasite species per host species was $7.1 \pm 3.4$, range $4-13$ ), and no individual frog harbored more than nine endoparasite species (mean number of endoparasite species per infected frog was $1.9 \pm$ 1.2 , range $1-9$ ).

\section{DISCUSSION}

All but two of the host species examined in this study are endemic to New Guinea and adjacent islands, reflecting the high level of endemism found in the Papuan biota (range maps for host taxa available at http:// www.bishopmuseum.org/research/pbs/ papuanherps/). As a result, it was not surprising to also discover a high degree of endemism among the helminths found in these frogs.

Of the digenean species found in this study, two species have wide geographic distribution and one species appears to be endemic. Diplodiscus amphichrus was described 
from specimens taken from several unidentified species of Rana collected in the Philippine Islands by Tubangui (1933). It is widely distributed in Asian frogs, having been reported from the Philippines, Vietnam, India, Korea, China, and Taiwan (Prudhoe and Bray 1982). Mesocoelium monas is cosmopolitan in distribution and is known from fishes, amphibians, and reptiles; records are summarized in Bursey et al. (2007c). Opisthioglyphe cophixali was originally described by Moravec and Sey (1989) from a microhylid frog, Cophixalus parkeri, collected on Mt. Otto, Papua New Guinea. It is curious that it should occur in our samples of Platymantis from offshore New Britain Island but not be found in our Rana samples from New Guinea, the island from which it was first described. This may perhaps reflect ecological differences inasmuch as Cophixalus and Platymantis are direct developers, whereas species of Rana lay eggs in water and have a tadpole stage. No other hosts have previously been reported.

Cestode cysticerci have been reported in Cyrtodactylus louisiadensis and Rana supragrisea (as "Sylvirana supragrisea") from Papua New Guinea (Bursey et al. 2005, 2008). Because these larvae occurred in cysts and caused no obvious cellular damage, we believe frogs can serve as paratenic hosts. Typically, these larvae when ingested by a definitive host would complete their life cycles (see Roberts and Janovy 2005).

Twelve of the nematode species found are currently known only from Papua New Guinea, three are found in the AustraloPapuan region, and two have wide distributions. Abbreviata oligopapillata was originally described as Physaloptera oligopapillata by Kreis (1940) from specimens taken from the skink Sphenomorphus jobiensis collected on New Britain, Bismarck Archipelago, but was assigned to Abbreviata by Morgan (1945). Jones (1979) reported it in an elapid snake, Acanthophis antarcticus, collected on New Guinea. Aplectana krausi was recently described from $P$. boulengeri from East New Britain Province, Papua New Guinea, by Bursey and Goldberg (2007). Our new records all came from congeneric hosts from the same island. Aplectana macintoshii is the most widely distributed member of the genus and is known from Africa, Europe, Southeast Asia, Japan, and South America; hosts are summarized in Bursey et al. (2008). It was originally described as Oxysoma macintoshii from specimens taken from Rana tigrina (currently Hoplobatrachus tigerinus) and Bufo stomaticus collected in India by Stewart (1914) and was reassigned to Aplectana by Travassos (1931). Aplectana zweifeli was described by Moravec and Sey (1986) from the frog Phrynomantis bumicola (currently Callulops bumicola) collected in Papua New Guinea. Bursey et al. (2005) found it in the skink Sphenomorphus jobiensis from Papua New Guinea. New Britain represents a new island record. Cosmocerca novaeguineae was originally described by Moravec and Sey (1990) from specimens taken from Platymantis papuensis collected in West Sepik Province, Papua New Guinea. New Britain represents a new island record. Cosmocerca tyleri was described by Bursey et al. (2006) from specimens taken from the microhylid frog Genyophryne thomsoni collected in the Cloudy Mountains, Milne Bay Province, Papua New Guinea. It was reported in the microhylid frog Hylophorbus cf. rufescens from Milne Bay Province, Papua New Guinea, by Bursey et al. (2007b). Our new record is also from that province. Desmognatbinema papuensis was described from Rana "grisea" from Eastern Highlands Province by Moravec and Sey (1990). Bursey et al. (2008) reported it in Rana supragrisea (as "Sylvirana supragrisea") from Mt. Simpson, Milne Bay Province, Papua New Guinea. Falcaustra papuensis was described from the scincid lizard Sphenomorphus simus from $\mathrm{Pa}-$ pua New Guinea by Bursey et al. (2007a). New Britain represents a new island record. Icosiella papuensis was described from $P$. papuensis from Papua New Guinea by Johnston (1967). Bursey et al. (2008) reported it in Rana supragrisea (as "Sylvirana supragrisea") from Normanby Island, Milne Bay Province, Papua New Guinea. Meteterakis crombiei was described from the skink Sphenomorphus jobiensis from Papua New Guinea by Bursey et al. (2005). New Britain represents a new island record. Ochoterenella papuensis was described from Platymantis papuensis by John- 


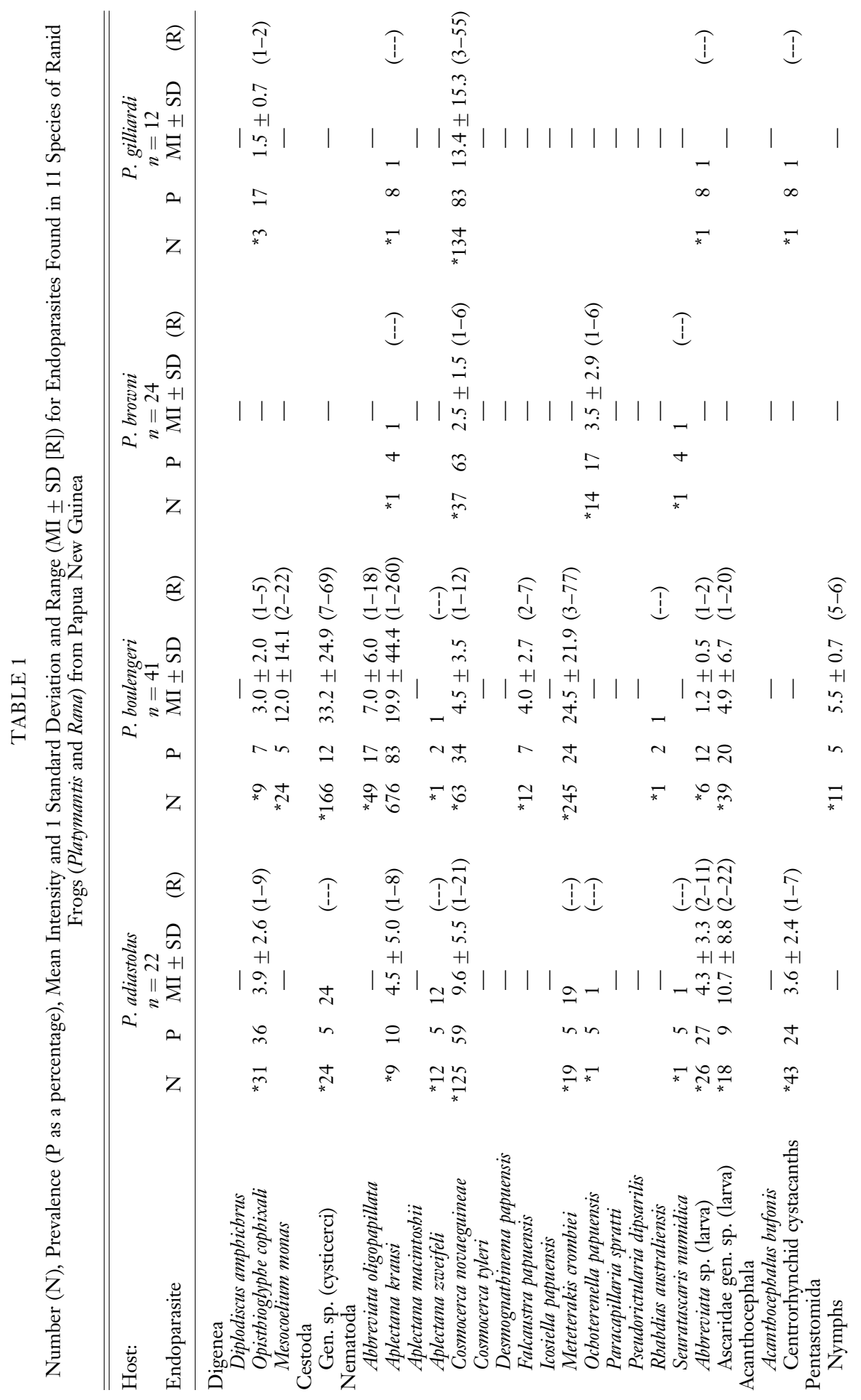




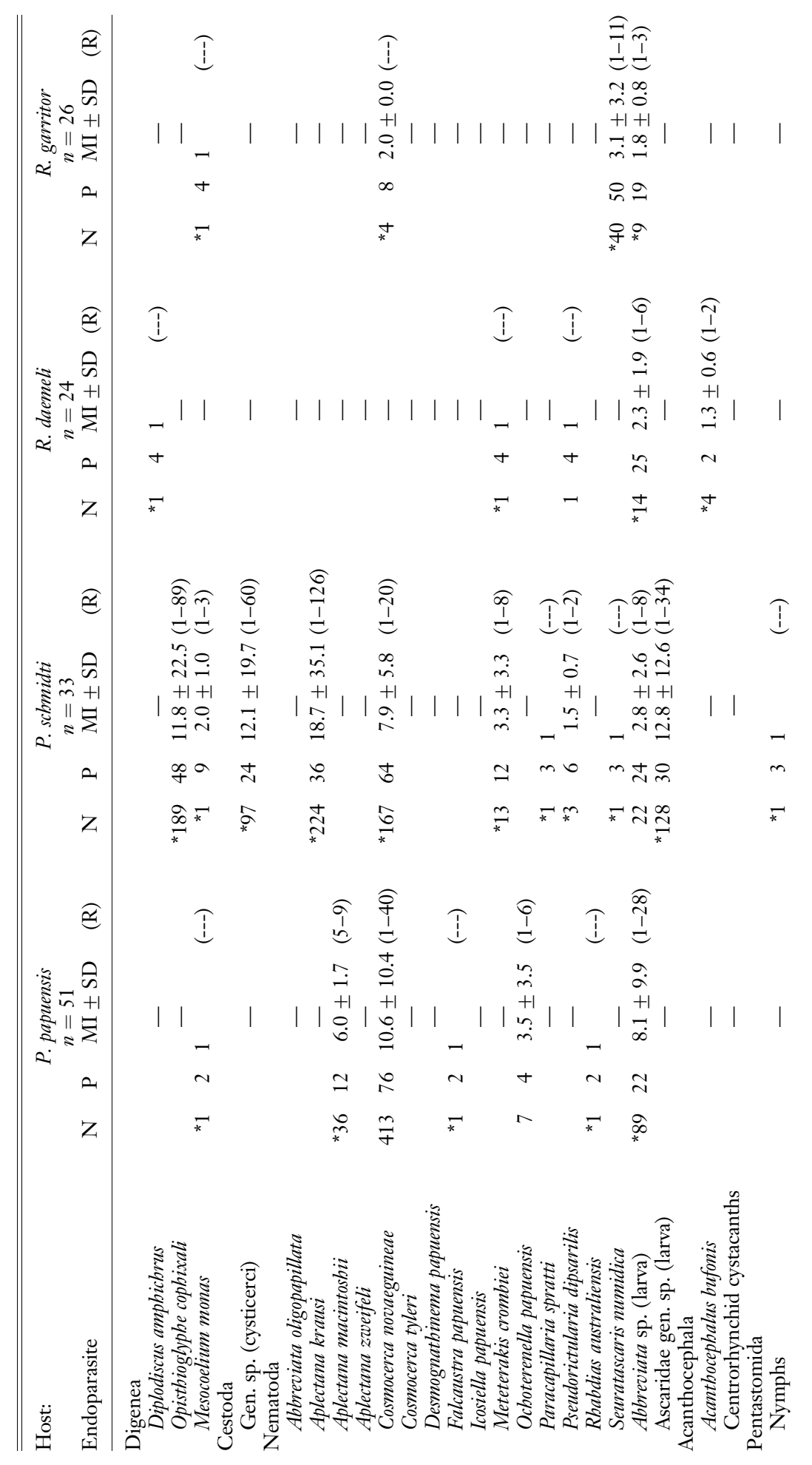




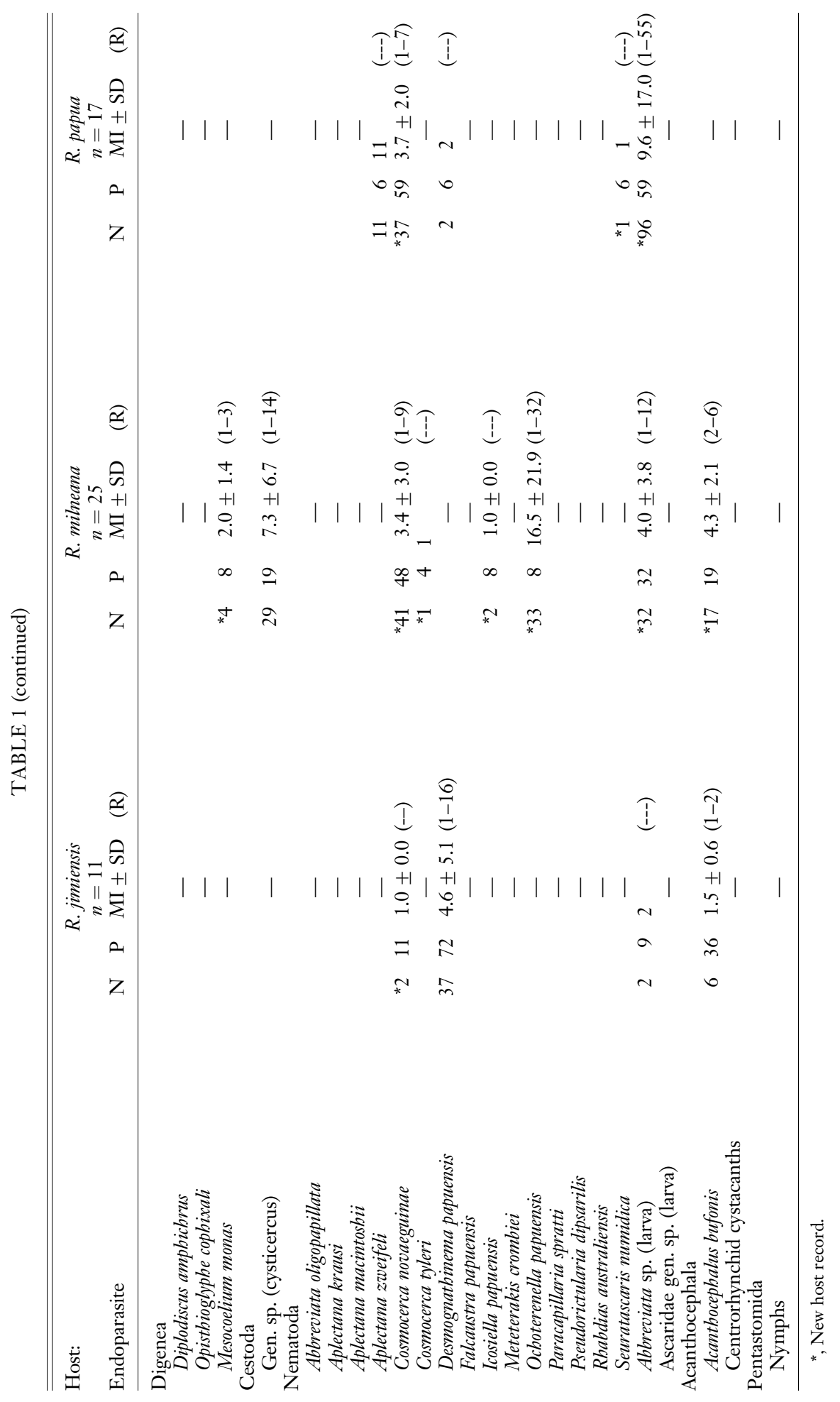


TABLE 2

Known Endoparasites of Papua New Guinean Ranid Frogs

\begin{tabular}{|c|c|c|c|c|c|c|c|c|c|c|c|c|c|c|c|c|}
\hline Parasite & 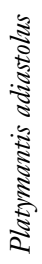 & 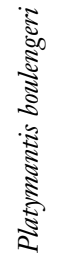 & 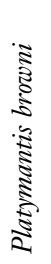 & 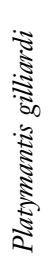 & 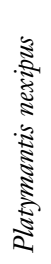 & 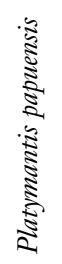 & 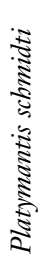 & $\begin{array}{l}\text { है } \\
\text { है } \\
\text { है } \\
2\end{array}$ & 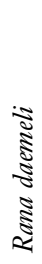 & 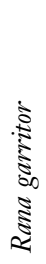 & 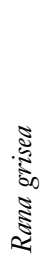 & 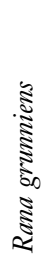 & 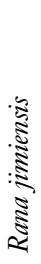 & 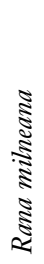 & 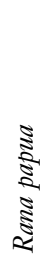 & 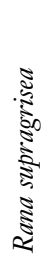 \\
\hline \multicolumn{17}{|l|}{ Papua New Guinea only } \\
\hline Dolichosaccus grandiacetabularis & -- & -- & -- & -- & -- & -- & -- & -- & -- & -- & 1 & -- & -- & -- & -- & -- \\
\hline Dolichosaccus longibursatus & -- & -- & -- & -- & -- & -- & -- & -- & -- & -- & -- & 1 & -- & -- & -- & -- \\
\hline Halipegus zweifeli & -- & -- & -- & -- & -- & -- & -- & -- & -- & -- & -- & 1 & -- & -- & -- & -- \\
\hline Opisthioglyphe cophixali & 2 & 2 & -- & 2 & 3 & -- & 2 & -- & -- & -- & -- & -- & -- & -- & -- & -- \\
\hline Proteocephalus niuginii & -- & -- & -- & -- & -- & -- & -- & 4 & -- & -- & -- & -- & -- & -- & -- & -- \\
\hline Proteocephalus papuensis & -- & -- & -- & -- & -- & -- & -- & -- & -- & -- & -- & -- & -- & -- & -- & 6 \\
\hline Aplectana krausi & 2 & 2,7 & 2 & 2 & 3 & -- & 2 & -- & -- & -- & -- & -- & -- & -- & -- & -- \\
\hline Aplectana zweifeli & 2 & 2 & -- & -- & -- & -- & -- & -- & -- & -- & -- & -- & -- & -- & 2 & -- \\
\hline Cosmocerca novaeguineae & 2 & 2 & 2 & 2 & 3 & 2,5 & 2 & -- & -- & 2 & -- & -- & 2 & 2 & 2 & 6 \\
\hline Cosmocerca tyleri & -- & -- & -- & -- & -- & -- & -- & -- & -- & -- & -- & -- & -- & 2 & -- & -- \\
\hline Desmognathinema papuensis & -- & -- & -- & -- & -- & -- & -- & -- & -- & -- & 5 & -- & 2 & -- & 2 & -- \\
\hline Falcaustra batrachiensis & -- & -- & -- & -- & 3 & -- & -- & -- & -- & -- & -- & -- & -- & -- & -- & -- \\
\hline Falcaustra papuensis & -- & 2 & -- & -- & -- & 2 & -- & -- & -- & -- & -- & -- & -- & -- & -- & -- \\
\hline Icosiella papuensis & -- & -- & -- & -- & 3 & 8 & -- & -- & -- & -- & -- & -- & -- & 2 & -- & 6 \\
\hline Meteterakis crombiei & 2 & 2 & -- & -- & -- & -- & 2 & -- & 2 & -- & -- & -- & -- & -- & -- & -- \\
\hline Ochoterenella papuensis & 2 & -- & 2 & -- & -- & 2,8 & -- & -- & -- & -- & -- & -- & -- & 2 & -- & -- \\
\hline Oswaldocruzia bakeri & -- & -- & -- & -- & -- & -- & -- & -- & -- & -- & -- & -- & -- & -- & -- & 6 \\
\hline Paracapillaria spratti & -- & -- & -- & -- & -- & -- & 2 & -- & -- & -- & -- & -- & -- & -- & -- & 6 \\
\hline \multicolumn{17}{|l|}{ Australo-Papuan } \\
\hline Abbreviata oligopapillata & -- & 2 & -- & -- & -- & -- & -- & -- & -- & -- & -- & -- & -- & -- & -- & -- \\
\hline Pseudorictularia dipsarilis & -- & -- & -- & -- & -- & -- & 2 & -- & 2 & -- & -- & -- & -- & -- & -- & 6 \\
\hline Rhabdias australiensis & -- & 2 & -- & -- & -- & 2 & -- & -- & - & -- & -- & -- & -- & -- & -- & -- \\
\hline Rokroknema novaebritanniae & -- & -- & -- & -- & 3 & -- & -- & -- & -- & -- & -- & -- & -- & -- & -- & -- \\
\hline \multicolumn{17}{|l|}{ Australo-Papuan and elsewhere } \\
\hline Diplodiscus amphichrus & -- & -- & -- & -- & -- & -- & -- & -- & 2 & -- & -- & -- & -- & -- & -- & -- \\
\hline Mesocoelium monas & -- & 2 & -- & -- & -- & 2 & 2 & -- & -- & 2 & -- & -- & -- & 2 & -- & -- \\
\hline Aplectana macintoshii & -- & -- & -- & -- & -- & 2 & -- & -- & -- & -- & -- & -- & -- & -- & -- & 6 \\
\hline Seuratascaris numidica & 2 & -- & 2 & -- & -- & -- & 2 & -- & -- & 2 & -- & -- & -- & -- & 2 & 6 \\
\hline Spinitectus ranae & -- & -- & -- & -- & -- & -- & -- & -- & -- & -- & -- & 5 & -- & -- & -- & -- \\
\hline Acanthocephalus bufonis & -- & -- & -- & -- & -- & -- & -- & -- & 2 & -- & -- & -- & 2 & 2 & -- & 6 \\
\hline \multicolumn{17}{|l|}{ Species not maturing in frogs } \\
\hline Cestoda (cysticercus) & 2 & 2 & -- & -- & -- & -- & 2 & -- & -- & -- & -- & -- & -- & 2 & -- & 6 \\
\hline Abbreviata sp. (larva) & 2 & 2 & -- & 2 & 3 & 2 & 2 & -- & 2 & 2 & -- & -- & 2 & 2 & 2 & 6 \\
\hline Ascaridae (larva) & 2 & 2 & -- & -- & -- & -- & 2 & -- & - & -- & -- & -- & -- & -- & -- & -- \\
\hline Physocephalus sp. (larva) & - & - & -- & -- & -- & -- & - & -- & -- & -- & -- & -- & -- & -- & -- & 6 \\
\hline Spinicaudinae (larva) & -- & -- & -- & -- & -- & -- & -- & -- & -- & -- & -- & -- & -- & -- & -- & 6 \\
\hline Acanthocephala (cystacanths) & 2 & -- & -- & 2 & 3 & -- & -- & -- & -- & -- & -- & -- & -- & -- & -- & 6 \\
\hline Kiricephalus sp. (nymphs) & -- & 2 & -- & -- & -- & -- & 2 & -- & -- & -- & -- & -- & -- & -- & -- & 6 \\
\hline
\end{tabular}

Note: Numerals refer to references: 1, Moravec and Sey (1989); 2, this paper; 3, Bursey et al. (2009); 4, Schmidt (1975); 5, Moravec and Sey (1990); 6, Bursey et al. (2008); 7, Bursey and Goldberg (2007); 8, Johnston (1967).

ston (1967) from Papua New Guinea. New Britain represents a new island record. Paracapillaria spratti was described from the microhylid frog Callulops stictogaster from Papua
New Guinea by Moravec and Sey (1986). It also was recorded from Callulops bumicola by Moravec (1990). New Britain represents a new island record. Pseudorictularia dipsarilis 
was described from the scincid lizard Pseudemoia entrecasteauxii from Flinders Island, South Australia, by Irwin-Smith (1922). Other hosts are listed in Bursey et al. (2008) and include frogs, lizards, and a mammal from Australia. Rhabdias australiensis was described by Moravec and Sey (1990) from Rana daemeli collected in Queensland, Australia. Papua New Guinea is a new locality record, and New Britain is a new island record. Seuratascaris numidica is known from a variety of anurans from Europe, the Orient, and Australia (see Baker 1987).

Larval nematodes found during this study require invertebrate intermediate hosts; thus it is probable that infection occurs by ingesting infected insects. Encysted larvae of Abbreviata sp. were found in the stomach wall of the frogs examined in this study, and ascarid larvae were found in the coelom, but these larvae are also common in the gastric tissues and body cavities of lizards and snakes from Australia (Jones 1995). Anurans most likely serve as paratenic hosts.

Acanthocephalus bufonis was originally described as Echinorbynchis bufonis from individuals taken from Bufo melanostictus in Thailand (Shipley 1903). Hosts for A. bufonis are listed in Bursey et al. (2008). Acanthocephalan cystacanths develop in an arthropod intermediate host until they become infective; infection occurs through ingestion, and in inappropriate hosts cystacanths migrate from the digestive tract into the body cavity and re-encyst (Schmidt 1985).

Adults of Kiricephalus pattoni inhabit respiratory passageways of numerous Indian, Southeast Asian, and Australian snakes (Riley and Self 1980); adults of Kiricephalus tortus are known only from New Guinea (Shipley 1898). Hosts for adults of these two species as well as hosts of nymphs are listed in Bursey et al. (2008).

As noted earlier, an important behavioral difference between the two genera of frogs examined in this study is that Rana species deposit eggs in water and these develop into tadpoles, whereas Platymantis species deposit eggs on land, where direct development occurs (Menzies 2006). Currently, 35 helminth species are known from Papua New Guinean ranid frogs (Table 2). Of these, 22 species occur in Platymantis and 27 species in Rana; however, only 14 species occur in both genera, which produces a Sorensen similarity index of 55 for the two genera. Whether the difference in endoparasitic species harbored by these hosts results from different developmental strategies or other behaviors will require further study, although our results for Opisthioglyphe cophixali suggest that this might be the case.

\section{ACKNOWLEDGMENTS}

We thank E. Teodoro, S. Kark, and S. Goldsberry for assistance with dissections. Innumerable people assisted with the fieldwork, and we thank the inhabitants and landowners of the areas listed in Appendix 1. Particular thanks go to Jim Anamiato, Sedeka Andrew, Ilaiah Bigilale, Fred Francisco, Bulisa Iova, Dyson Libai, Fred Malesa, David Mitchell, Florence Paisparea, Pesto Roberts, Bendo Salepuna, Stanley Simalken, John Slapeinsky, and Ben Yawi for providing logistical assistance. We thank the PNG National Museum and Art Gallery for providing in-country collaborative assistance and the Department of Environment and Conservation, National Research Institute, and Central, East New Britain, Milne Bay, and West Sepik provincial governments for permission to conduct this research.

\section{Literature Cited}

Baker, M. R. 1987. Synopsis of the Nematoda parasitic in amphibians and reptiles. Memorial Univ. Newfoundland Occas. Pap. Biol. 11:1-325.

Bursey, C. R., and S. R. Goldberg. 2007. A new species of Aplectana (Nematoda, Cosmocercidae) in Platymantis boulengeri (Anura, Ceratobatrachidae) from Papua New Guinea. Acta Parasitol. 52:368-370.

Bursey, C. R., S. R. Goldberg, and F. Kraus. 2005. Endoparasites in Sphenomorphus jobiensis (Sauria: Scincidae) from Papua New Guinea with description of three new species. J. Parasitol. 91:1385-1394.

- 2006. A new species of Cosmocerca 
(Nematoda, Cosmocercidae) and other helminths from Genyophryne thomsoni (Anura, Microhylidae) from Papua New Guinea. Acta Parasitol. 51:213-216.

- 2007a. A new species of Falcaustra (Nematoda, Kathlaniidae) and other nematodes from Sphenomorphus simus (Squamata, Scincidae) from Papua New Guinea. Acta Parasitol. 52:142-145.

- 2007b. A new species of Moaciria (Nematoda, Heterakidae) and other helminths in the red Mawatta frog, Hylophorbus cf. rufescens (Anura, Microhylidae) from Papua New Guinea. Acta Parasitol. 52:233-237.

. 2008. A new species of Proteocephalus (Cestoda: Proteocephalidae), description of the male of Desmognathinema papuensis (Nematoda: Quimperiidae), and other endoparasites in Sylvirana supragrisea (Anura: Ranidae) from Papua New Guinea. Comp. Parasitol. 75:33-48.

. 2009. New genus of Pharyngodonidae (Nematoda: Oxyuridea) and other helminths in Platymantis nexipus (Anura: Ranidae) from Papua New Guinea. J. Parasitol. (in press).

Bursey, C. R., S. R. Goldberg, and S. R. Telford Jr. 2007c. Gastrointestinal helminths of 14 species of lizards from Panama with descriptions of five new species. Comp. Parasitol. 74:108-140.

Bush, A. O., K. D. Lafferty, J. M. Lotz, and A. W. Shostak. 1997. Parasitology meets ecology on its own terms: Margolis et al. revisited. J. Parasitol. 83:575-583.

Irwin-Smith, V. 1922. A new nematode parasite of a lizard. Proc. Linn. Soc. N. S. W. 47:311-318.

Johnston, M. R. L. 1967. Icosiella papuensis n. sp. and Ochoterenella papuensis n. sp. (Nematoda, Filarioidea), from a New Guinea frog, Cornufer papuensis. J. Helminthol. 41:45-54.

Jones, H. I. 1979. Nematodes from Papua New Guinean snakes. Mem. Queensl. Mus. 19:393-397.

- 1995. Pathology associated with physalopterid larvae (Nematoda: Spirurida) in the gastric tissues of Australian reptiles. J. Wildl. Dis. 31:710-715.
Kreis, H. A. 1940. Beitrage zur Kentnis parasitischer Nematoden. IX. Parasitische Nematoden aus dem Naturhistorischen Museum Basel. Centralbl. Bakteriol., Parasitenkd. Infektionskr. 145:163-208.

Menzies, J. 2006. The frogs of New Guinea and the Solomon Islands. Pensoft Publishers, Sofia, Bulgaria.

Moravec, F. 1990. Additional records of nematode parasites from Papua New Guinea amphibians with a list of recorded endohelminths by amphibian hosts. Folia Parasitol. (Prague) 37:43-58.

Moravec, F., and O. Sey. 1986. Three new nematode species from Phrynomantis spp. (Amphibia: Microhylidae) from Papua New Guinea. Folia Parasitol. (Prague) 33:343-351.

. 1989. Some amphibian trematodes from Vietnam and Papua New Guinea. Vestn. Cesk. Spol. Zool. 53:265-279.

- 1990. Some nematode parasites of frogs from Papua New Guinea and Australia. Acta Soc. Zool. Bohem. 54:268-286.

Morgan, B. B. 1945. The nematode genus Abbreviata (Travassos, 1920) Schulz, 1927. Am. Midl. Nat. 34:485-490.

Prudhoe, S., and R. A. Bray. 1982. Platyhelminth parasites of the Amphibia. British Museum (Natural History), Oxford University Press, Oxford, United Kingdom.

Riley, J., and J. T. Self. 1980. On the systematics and life-cycle of the pentastomid genus Kiricephalus Sambon, 1922 with descriptions of three new species. Syst. Parasitol. 1:127-140.

Roberts, L. S., and J. Janovy Jr. 2005. Gerald D. Schmidt \& Larry S. Roberts' Foundations of parasitology. 7th ed. McGrawHill Higher Education, Boston.

Schmidt, G. D. 1975. New records of helminthes from New Guinea, including description of three new cestode species, one in the new genus Wallabicestus n.g. Trans. Am. Microsc. Soc. 94:189-196.

- 1985. Development and life cycles. Pages 273-306 in D. W. T. Crompton and B. B. Nickol, eds. Biology of the Acanthocephala. Cambridge University Press, Cambridge, United Kingdom.

Shipley, A. E. 1898. An attempt to revise the 
family Liguatulidae. Arch. Parasitol. 1:5280.

1903. On the ento-parasites collected by the "Skeat Expedition" to lower Siam and the Malay Peninsula in the years 1899-1900. Proc. Zool. Soc. Lond. $2: 145-156$.

Stewart, F. H. 1914. Studies in Indian helminthology, No. 1. Rec. Indian Mus. (Calcutta) 10:165-193.

Travassos, L. 1931. Pesquizas helminthologicos realizadas em Hamburgo. IX. Ensaio monographico da familia Cosmocercidae Trav., 1925 (Nematoda). Mem. Inst. Oswaldo Cruz 25:237-298.

Tubangui, M. A. 1933. Trematode parasites of Philippine vertebrates, VI: Descriptions of new species and classification. Philipp. J. Sci. 52:167-197.

\section{Appendix 1}

Ranid Frog Specimens from Papua New Guinea Examined from the Herpetology Collection of the Bernice P. Bishop Museum (в ввм), Honolulu, Hawai'i, or Fred Kraus Field Tag (FK)

Platymantis adiastolus $(n=22)$, East New Britain Province: $11.3 \mathrm{~km}$ NNW Marmar (врвм 22211), $9 \mathrm{~km}$ NNW Marmar (врвм 22362, 22365, 22366, 2236922380), $2.6 \mathrm{~km}$ NNW Marmar (врвм 22383-22388).

Platymantis boulengeri $(n=41)$, East New Britain Province: 0-9.5 km NNW Mamar (врвм 22212-22221, 22223-22332, 22334-22337, 22343, 22345-22348, 22350-22361).

Platymantis browni $(n=24)$, East New Britain Province: 9 km NNW Marmar (врвм 22229-22246, 22248, 22250-22252, 22256, 22257).

Platymantis gilliardi $(n=12)$, East New Britain Province: 8.8-11.3 km NNW Marmar (врвм 22259-22666), $2.6 \mathrm{~km}$ NNW Marmar (врвм 22267-22270).

Platymantis papuensis $(n=52)$, Milne Bay Province: Alotau, Kinahidamadamana River (врвм 15467), $9.5 \mathrm{~km}$ W Alotau (врвм 15469-15476), Top of Huhuna Road, 300 m (врвм 15478-15481, 16287-16304, 17078-17082, 17825, 17826, 18513-18515, 22799_ 22808); West Sepik Province: Parkop (FK 11404).

Platymantis schmidti $(n=33)$, East New Britain Province, Marmar (врвм 22279, 22281-22292, 22294-22306, 22308, 22363, 22364, 22381, 22382, FK 10977, 10978)

Rana daemeli $(n=24)$, Milne Bay Province: Alotau (врвм 15482), Nigila $13.7 \mathrm{~km} \mathrm{E} \mathrm{Alotau} \mathrm{(врвм} \mathrm{15483-}$ 15486), Halowia $15.8 \mathrm{~km} \mathrm{E} \mathrm{Alotau} \mathrm{(врвм} \mathrm{16305,}$ 16307, 16308, 16309-16311, 16313, 16314), Alotau, Kinahidamadamana River (врвм 163615, 16316), Kivikivi (врвм 17074); East New Britain Province: Pomio (врвм 22391-22398).
Rana garritor $(n=26)$, Milne Bay Province: SE slope Mt. Pekopekowana (врвм 15488-15490, 15492-15499, 15501-15513), Cloudy Mts., Upaelisafupi Stream (врвм 15746, 15747).

Rana jimiensis $(n=11)$, West Sepik Province: Torricelli Mts., SSW slope Mt. Sapau (врвм 22831-22839, 22841, 22842).

Rana milneana $(n=25)$, Milne Bay Province: Alotau, Kinahidamadamana River (врвм 15749, 15750, 16377-16380), SE slope Mt. Pekopekowana (врвм 15751-15753), Fergusson Island (врвм 1636016363), Normanby Island (врвм 16366, 16372 16376, 17075-17077); Central Province: Iamarere (врвм 22399-22401).

Rana papua $(n=17)$, Milne Bay Province: Normanby Island, Sewa Bay (врвм 16321-16326, 16329-16335, 16896); West Sepik Province: Parkop (врвм 22843 22845).

\section{Appendix 2}

Helminths from Papua New Guinea Deposited in the U.S. National Parasite Museum (USNPC), Beltsville, Maryland, or the Bernice P. Bishop Museum (врвм), Honolulu, Hawai'i

Platymantis adiastolus: Opisthioglyphe clophixali (USNPC 100859); cestode cysticercus (USNPC 100860); Aplectana krausi (USNPC 100861); Aplectana zweifeli (USNPC 100862); Cosmocerca novaeguineae (USNPC 100863; врвм H282); Meteterakis crombiei (USNPC 100864); Ochoterenella papuensis (USNPC 100865); Seuratascaris numidica (USNPC 1000866); Abbreviata sp. (USNPC100867; врвм H280); ascarid larvae (USNPC 100868; врвм H281); Acanthocephala cystacanth (USNPC 100869).

Platymantis boulengeri: Mesocoelium monas (USNPC 100870; в ввм F299); Opisthioglyphe cophixali (USNPC 100871, 100872; врвм F300, F301, F302); Cestoda cysticercus (USNPC 100873, 100874; врвм F303); Abbreviata oligopapillata (USNPC 100875, 100876; врвм Н283, H284); Aplectana krausi (USNPC 100877, 100878; врвм H285, H286); Aplectana zweifeli (USNPC 100879); Cosmocerca novaeguineae (USNPC 100880); Falcaustra papuensis (USNPC 100881; врвм H287); Meteterakis crombiei (USNPC 100882; вРвм H288); Rbabdias australiensis (USNPC 100883); Abbreviata sp. (USNPC 100884; врвм Н289); ascarid larvae (USNPC 100885, 100886; врвм H290, H291); Pentastomida nymph (USNPC 100887; врвм Н292).

Platymantis browni: Aplectana krausi (USNPC 100888); Cosmocerca novaeguineae (USNPC 100889; вРвм H293); Ochoterenella papuensis (USNPC 100890; врвм H294); Seuratascaris numidica (USNPC 100891).

Platymantis gilliardi: Opisthioglyphe cophixali (USNPC 100892; врвм F304); Aplectana krausi (USNPC 100893); Cosmocerca novaeguineae (USNPC 100894; врвм H295); Abbreviata sp. (USNPC 100895); Acanthocephala cystacanth (USNPC 100896).

Platymantis papuensis: Mesocoelium monas (USNPC 
100897); Aplectana krausi (USNPC 100898); Cosmocerca novaeguineae (USNPC 100899; врвм H296); Falcaustra papuensis (USNPC 100900); Ochoterenella papuensis (USNPC 100901; в ввм H297); Abbreviata sp. (USNPC 100902; в ввм H298).

Platymantis schmidti: Mesocoelium monas (USNPC 100903; врвм F305); Opisthioglyphe cophixali (USNPC 100904; врвм F306, F307); Cestoda cycticercus (USNPC 100905; врвм F308, F309); Aplectana krausi (USNPC 100906; врвм H299); Cosmocerca novaeguineae (USNPC 100907); Meteterakis crombiei (USNPC 100908); Paracapillaria spratti (USNPC 100909); Pseudorictularia dipsarilis (USNPC 100910); Abbreviata sp. (USNPC 100911); ascarid larvae (USNPC 100912; врвм Н300); Pentastomida nymph (USNPC 100913).
Rana daemeli: Diplodiscus amphichrus (USNPC 100914); Meteterakis crombiei (USNPC 100915).

Rana garritor: Mesocoelium monas (USNPC 100916; врвм F310); Abbreviata sp. (USNPC 100917; в ввм H301).

Rana jimiensis: Cosmocerca novaeguineae (USNPC 100918); Desmognatbinema papuensis (USNPC 100919; в ввм H302); Abbreviata sp. (USNPC 100920); Acanthocephalus bufonis (USNPC 100921; врвм Н303).

Rana milneana: Mesocoelium monas (USNPC 100922; врвм F311); Cestoda, cysticercus (USNPC 100923; в ввм F312); Icosiella papuensis (USNPC 100924); Ochoterenella papuensis (USNPC 100925; в вм H304). Rana papua: Aplectana zweifeli (USNPC 100926); Desmognathinema papuensis (USNPC 100927; врвм Н305); Seuratascaris numidica (USNPC 100928); Abbreviata sp. (USNPC 100929; врвм Н306). 
